\title{
Clinical features of the pulmonary tuberculosis course combined with different diabetes mellitus types in the Zaporizhzhia region
}

\author{
0. M. Raznatovska, Yu. M. Bobrovnycha-Dvizova
}

Zaporizhzhia State Medical University, Ukraine

The purpose of the work - to determine the clinical features of the pulmonary tuberculosis course combined with different types of diabetes mellitus $(\mathrm{DM})$ in the Zaporizhzhia region for the further development of the differentiated approach to the management of these patients.

Materials and methods of research. The study included 49 patients with pulmonary tuberculosis who were in inpatient treatment in the Departments of Clinical site of the tuberculosis and pulmonology department of the ZSMU in the "Zaporizhzhia Regional Clinical TB Dispensary" Municipal institution. The patients were divided into 2 groups: a group of $1-31$ patients with pulmonary tuberculosis combined with the 1 type DM course, a group of 2 to 18 patients with pulmonary tuberculosis combined with the 2 type DM course. The outcomes of the study were processed by modern analysis methods on a personal computer using the statistical package of the Statistica ${ }^{\circledR}$ for Windows 6.0 (StatSoft Inc., No. AXXR712 D833214FAN5) license program.

Results. In tuberculosis patients with the combined type 1 DM course, regardless of sex, young people aged 31-40 years significantly predominate, and with type 2 diabetes - men over 40 years of age. In tuberculosis patients with the combined type $1 \mathrm{DM}$ course, the infiltrative form of tuberculosis is 1.5 times more frequent than that of type $2 \mathrm{DM}$. In the case of the combined type $1 \mathrm{DM}$ course, the tendency towards the infiltrative form predominance is determined, but compared to type 1 diabetes, the disseminated form is 10.4 times predominant. The vast number of patients in both groups are patients with bacterial excretion, and on discharge from hospital, the number of patients with bacterial excretion with the combined type $2 \mathrm{DM}$ course remains 1.7 times larger. Regardless of the concomitant DM type, the vast majority of patients have a destructive process in the lungs with a predominance of cavities up to $4 \mathrm{~cm}$ in diameter, regardless of their number. Despite the fact that regardless of the concomitant DM type, the average time of the destructions healing in both groups is almost equal (5 months), in patients with type $2 \mathrm{DM}$ there is a tendency to 2 times more frequent healing of destructions. Type $1 \mathrm{DM}$ is of the predominantly severe and moderate severity in the subcompensation stage, and type 2 diabetes in almost all patients is of moderate severity with a tendency to the predominance of the decompensation stage. Regardless of the concomitant DM type, in the half of patients in the setting of the TB course combined with DM, the concomitant conditions are diagnosed: hypertonic disease and pulmonary heart failure in patients with the combined type 2 diabetes are prevalent in comparison with the patients with type $1 \mathrm{DM}$, where there is a tendency to increase in the pulmonary heart failure and hepatitis incidence. In TB patients, the complications of DM develop 1.3 times more frequent with type 1 than with type 2 , which are manifested predominantly by diabetic vascular disorders, namely, retinal angiopathy and lower extremity angiopathy and ketoacidosis. And complications of type 2 diabetes are diabetic: vascular disorders, encephalopathy and diabetic foot. Regardless of the concomitant diabetes type, the incidence of adverse reactions to antimycobacterial drugs in cases of resistant tuberculosis is $37.5 \%$ in patients with the combined type $1 \mathrm{DM}$ and $44.4 \%$ with the combined type $2 \mathrm{DM}$. In cases of tuberculosis with the combined type $2 \mathrm{DM}, 5$ times more patients have been provided with the palliative therapy.

Conclusions. The course of tuberculosis largely depends on the type of diabetes. When combined with type 1 diabetes, the more unfavorable and severe course of both diseases is determined, while in combination with type 2 diabetes, on the contrary.

\section{Кмінічні особливості поєднаного перебігу туберкульозу мегень із різними типами цукрового діабету}

\section{О. М. Разнатовська, Ю. М. Бобровнича-Авізова}

Мета роботи - визначити клінічні особливості поєднаного перебігу туберкульозу легень із різними типами цукрового діабету (ЦД) у Запорізькій області для дальшої розробки диференційованого підходу до ведення цих пацієнтів.

Матеріали та методи. У дослідження включили 49 хворих на туберкульоз легень, які перебували на стаціонарному лікуванні у відділеннях клінічної бази кафедри фртизіатрії і пульмонології ЗДМУ в КУ «Запорізький обласний протитуберкульозний клінічний диспансер». Хворі були поділені на 2 групи: 1 - 31 хворий на туберкульоз легень із поєднаним перебігом ЦД 1 типу, група 2 - 18 хворих на туберкульоз легень із поєднаним перебігом ЦД 2 типу. Результати дослідження опрацьовані сучасними методами аналізу на персональному комп'ютері з використанням статистичного пакета ліцензійної програми Statistica ${ }^{\circledR}$ for Windows 6.0 (StatSoft Inc., № AXXR712 D833214FAN5).

Результати. У хворих на туберкульоз із поєднаним перебігом ЦД 1 типу, незалежно від статі, вірогідно переважають молоді особи віком 31-40 років, а з ЦД 2 типу - чоловіки (старші за 40 років). У хворих на туберкульоз із поєднаним перебігом ЦД 1 типу у 1,5 раза частіше переважає інфільтративна форма туберкульозу, ніж із ЦД 2 типу. А при поєднаному перебігу з ЦД 1 типу визначається тенденція до переважання інфільтративної форми, але порівняно з ЦД 1 типу у 10,4 раза переважає дисемінована. Переважна кількість пацієнтів обох груп - бактеріовиділювачі, а під час виписки зі стаціонара кількість пацієнтів із бактеріовиділенням при поєднаному перебігу з ЦД 2 типу залишається більшою в 1,7 раза. Незалежно від типу супутнього ЦД, основна кількість пацієнтів мають деструктивний процес із переважанням каверн до 4 см діаметром, незалежно від їхньої кількості. Притім, що, незалежно від типу супутнього ЦД, середні терміни загоєння деструкцій в обох групах майже однакові (5 місяців), при ЦД 2 типу визначається тенденція до частішого вдвічі загоєння
Key words:

tuberculosis, diabetes mellitus.

\section{Zaporozhye} medical journal 2017; $19(6), 773-779$ DOI: 10.14739/2310-1210. 2017.6.115014

E-mail: raxnatovskaya@ gmail.com 
деструкцій. ЦД 1 типу - переважно тяжкого та середньотяжкого ступенів тяжкості у стадії субкомпенсації, а ЦД 2 типу майже в усіх пацієнтів - середньотяжкого ступеня з тенденцією до переважання стадії декомпенсації. Незалежно від типу супутнього ЦД, у половини пацієнтів на тлі поєднаного перебігу туберкульозу з ЦД діагностуються супутні захворювання: у хворих із поєднаним ЦД 2 типу переважають гіпертонічна хвороба та легенево-серцева недостатність порівняно 3 хворими на ЦД 1 типу, де визначається тенденція до зростання частоти легенево-серцевої недостатності та гепатитів. У хворих на туберкульоз ускладнення ЦД розвиваються частіше у 1,3 раза при 1 типі, ніж при 2, проявляються переважно діабетичними судинними розладами, як-от: ангіопатіями сітківки ока та нижніх кінцівокі кетоацидозом. А ускладненнями ЦД 2 типу є діабетичні: судинні розлади, енцефалопатія та діабетична стопа. Незалежно від типу супутнього ЦД, частота побічних реакцій на антимікобактеріальні препарати у випадках резистентного туберкульозу становить 37,5 \% у хворих із поєднаним ЦД 1 типу та 44,4 \% - з поєднаним ЦД 2 типу. При туберкульозі з поєднаним ЦД 2 типу у 5 разів частіше пацієнти переведені на паліативне лікування.

Висновки. Перебіг туберкульозу значно залежить від типу супутнього цукрового діабету. При поєднанні з цукровим діабетом 1 типу визначається несприятливіший і тяжкий перебіг обох захворювань, а при поєднанні з цукровим діабетом 2 типу - навпаки.

\section{Ключевые слова: \\ туберкулез, сахарный диабет. \\ Киинические особенности сочетанного течения туберкулеза легких с различными типами сахарного диабета}

\section{Е. Н. Разнатовская, Ю. М. Бобровничая-Авизова}

Цель работы - определение клинических особенностей сочетанного течения туберкулеза легких с различными типами сахарного диабета (СД) в Запорожской области для дальнейшей разработки дифференцированного подхода к ведению этих пациентов.

Материалы и методы. В исследовании приняли участие 49 пациентов с туберкулезом легких, которые прошли стационарное лечение в отделениях клинической базы кафедры фтизиатрии и пульмонологии ЗГМУ в КУ «Запорожский областной туберкулезный клинический диспансер». Пациенты разделены на 2 группы: группа 1 - 31 больной туберкулезом легких с сочетанным течением СД 1 типа, группа 2 - 18 больных туберкулезом легких с сочетанным течением СД 2 типа. Результаты исследования обработаны современными методами анализа на персональном компьютере с использованием статистического пакета лицензионной программы STATISTICA® для Windows 6.0 (Stat Soft Inc., AXXR712 D833214FAN5).

Результаты. У больных туберкулезом с сочетанным течением СД 1 типа, независимо от пола, достоверно преобладают молодые люди в возрасте 31-40 лет, а с СД 2 типа - мужчины старше 40 лет. У больных туберкулезом с сочетанным течением СД 1 типа в 1,5 раза чаще преобладает инфильтративная форма туберкулеза, чем при СД 2 типа. А при сочетанном течении с СД 1 типа определяется тенденция к преобладанию инфильтративной формы, но по сравнению с СД 1 типа в 10,4 раза превышает диссеминированная. Подавляющее количество пациентов обеих групп являются бактериовыделителями, а при выписке из стационара количество пациентов с бактериовыделением при сочетанном течении с СД 2 типа остается больше в 1,7 раза. Независимо от типа сопутствующего СД подавляющее количество пациентов имеют деструктивный процесс в связи с преобладанием каверн до 4 см в диаметре, независимо от их количества. Притом, независимо от типа сопутствующего СД, средние сроки заживления деструкции в обеих группах почти одинаковые (5 месяцев), при СД 2 типа определяется тенденция к более частому в 2 раза заживлению деструкций. СД 1 типа преимущественно тяжелой и среднетяжелой степени тяжести - в стадии субкомпенсации, а СД 2 типа почти у всех пациентов - среднетяжелой степени с тенденцией к преобладанию стадии декомпенсации. Независимо от типа сопутствующего СД, у половины пациентов на фоне сочетанного течения туберкулеза с СД диагностируются сопутствующие заболевания: с сочетанным течением СД 2 типа преобладают гипертоническая болезнь и легочно-сердечная недостаточность по сравнению с больными с СД 1 типа, где определяется тенденция к росту частоты легочно-сердечной недостаточности и гепатитов. У больных туберкулезом осложнения СД развиваются чаще в 1,3 раза при 1 типе, чем при 2 типе, проявляются преимущественно диабетическими сосудистыми расстройствами, а именно: ангиопатиями сетчатки глаза и нижних конечностей и кетоацидозом. Осложнениями СД 2 типа являются диабетические сосудистые расстройства и энцефалопатия, диабетическая стопа. Независимо от типа сопутствующего СД, частота побочных реакций на антимикобактериальные препараты в случаях резистентного туберкулеза составляет 37,5 \% у больных с СД 1 типа и 44,4 \% - СД 2 типа. При туберкулезе с сочетанным течением СД 2 типа на паллиативное лечение переведено в 5 раз больше пациентов.

Выводы. Течение туберкулеза значительно зависит от типа сопутствующего сахарного диабета. При сочетании с сахарным диабетом 1 типа определяется более неблагоприятное и тяжелое течение обоих заболеваний, а при сочетании с сахарным диабетом 2 типа - наоборот.

Currently, the number of patients with the tuberculosis course combined with other diseases has been increasing in Ukraine. The combination of tuberculosis and diabetes mellitus (DM), which mutually complicate the progress of each other [1,2], deserves special attention.

$\mathrm{DM}$ - a group of metabolic diseases, which are divided into 2 types [3,4]. Type 1 diabetes is an insulin dependent disease that develops predominantly in young people and is characterized by hyperglycemia. Type 2 diabetes is a disease predominantly with a slow onset, mostly occurs in adults and associated with the metabolic syndrome signs.

In 2012, we performed an analysis of literature on the determining features of the pulmonary tuberculosis course combined with preserved sensitivity of Mycobacterium tuberculosis (MBT) to antimycobacterial drugs (AMBD) and $\mathrm{DM}$, depending on its type [1]. The data from literary sources indicated that in the mild and moderate tuberculosis course 
combined with type $1 \mathrm{DM}$, limited forms of a specific process without destruction were diagnosed, and in the severe disease, the prevalent forms with a rapid progress of the destructive process were diagnosed. The combined course with type 2 diabetes develops predominantly in patients with repeated cases of tuberculosis and is characterized by asymptomatic course and slow progression.

Scientific works by Komyssarova O. G. et al (2013, 2015) $[2,5]$ are dedicated to the study of the diabetes course features, depending on its type, in patients with multidrug-resistant tuberculosis (MDRTB). The authors have specified that the MDRTB course combined with type 1 DM develops predominantly in patients under the age of 29 years and is characterized by a widespread infiltrative destructive process in the lungs. The MDRTB course combined with type 2 DM is mainly diagnosed in individuals over the age of 50 years and is characterized by a predominance of fibrous-cavernous form. In the setting of massive combination therapy (AMBD, treatment of DM, pathogenetic and symptomatic), the authors found that the frequency of conversion in the MRTB patients depending on the diabetes type was not significantly different and was up to $75 \%$, and the period of destruction healing was definitely 1 month shorter in patients with the combined type $1 \mathrm{DM}$ course.

As can be seen in TB patients, both with the preserved MBT sensitivity to AMBD and with MDRTB, type 1 diabetes develops mainly in young people and is characterized by widespread infiltrative destructive processes in the lungs, and type $2 \mathrm{DM}$ - in patients over the age of 50 years and characterized by the predominance of fibrous-cavernous forms with a slowly progress. However, the therapy for this combined course of two serious diseases, such as tuberculosis and diabetes, should be comprehensive and in the setting of standard antimycobacterial therapy (AMBT) include treatment of diabetes, the use of pathogenetic and symptomatic agents.

Today in Ukraine there is no data on the differentiated approach to the management of patients with tuberculosis combined with the DM course depending on its type, thereby slowing the progression of both tuberculosis and DM, which would increase treatment efficacy and improve the quality of these patients' life.

\section{The purpose of the work}

To determine the clinical features of the pulmonary tuberculosis course combined with different types of DM in the Zaporizhzhia region for the further development of the differentiated approach to the management of these patients.

\section{Materials and methods of research}

The study included 49 patients with pulmonary tuberculosis who were in inpatient treatment in the Departments of Clinical site of the tuberculosis and pulmonology department of the ZSMU in the "Zaporizhzhia Regional Clinical TB Dispensary" Municipal institution. The patients were divided into 2 groups: a group of $1-31$ patients with pulmonary tuberculosis combined with the 1 type DM course, a group of 2 to 18 patients with pulmonary tuberculosis combined with the 2 type DM course.
Table 1. Characteristics of patients by age

\begin{tabular}{llllllll}
\hline Patients group & total & \multicolumn{6}{l}{ Patients age (years) } \\
\cline { 3 - 8 } & & & $\mathbf{1 8 - 3 0}$ & $\mathbf{3 1 - 4 0}$ & over 41 \\
\cline { 3 - 8 } & & abs. & $\%$ & abs. & $\%$ & abs. & $\%$ \\
\hline Group 1 & 31 & 3 & 9.7 & 11 & $35.5^{\#}$ & 17 & 54.8 \\
Group 2 & 18 & 1 & 5.6 & 1 & 5.6 & 16 & $88.8^{*}$ \\
\hline
\end{tabular}

*: significant difference in the indicator within the group $(P<0.05)$; \#: significant difference in the indicator between the groups $(P<0.05)$.

According to the "Tuberculosis" medical care unified clinical protocol [6], the TB cases with preserved MBT sensitivity to AMBD included - first diagnosed pulmonary tuberculosis (FDTB), tuberculosis treatment failure (TBTF) and tuberculosis recurrence (TBR) and resistant tuberculosis cases include the multi-resistant tuberculosis risk (MDRT$B R$ ), rifampicin resistant tuberculosis (RifTB), MDRTB, and extensively drug-resistant tuberculosis (EDRTB). Cases of completed treatment were considered as residual changes after cured tuberculosis (RCTB).

The outcomes of the study were processed by modern analysis methods on a personal computer using the statistical package of the Statistica ${ }^{\circledR}$ for Windows 6.0 (Stat Soft Inc., No. AXXR712 D833214FAN5) license program. The normality of distribution of quantitative characteristics was analyzed using the Shapiro-Wilk test. Non-parametric statistical criteria (four-field matrix analysis $-x^{2}$ criterion) were used to determine the significant differences between qualitative indicators. All tests were bidirectional. $P<0.05$ was considered as the statistically significant difference.

\section{The outcomes and their discussion}

In the process of the patients sex distribution, it was found that among the patients of group 1, the men (24 $(77.4 \%)$ versus 7 women $\left.(22.6 \%), X^{2}=4.66, p<0.05\right)$ prevailed, and in group 2 the frequency of men and women was equal (9 (50\%) and $9(50 \%) ; p>0.05)$.

Table 1 shows the characteristics of patients by age. While there was no significant age difference in group 1 , there was a tendency to increase in the number of patients with the age increased and in comparison with group 2 the persons aged $31-40$ years prevailed $(35.5 \%$ versus $5.6 \%, P<0.05)$. In group 2 , the patients over the age of 41 prevailed $\left(X^{2}=16.66 ; P<0.01\right)$. The average age of patients in group 1 was 12 years less than in group 2 (42.7 \pm 1.9 versus $54.8 \pm 2.7$ years; $P<0.05)$.

Analysis of clinical forms (Fig. 1) showed that in the vast majority of patients in group 1 , the infiltrative form of tuberculosis was diagnosed $\left(X^{2}=63.23 ; P<0.001\right)$, which is 1.5 times more frequent than in group 2 (83.9\% versus $55.5 \%$; $P<0.05)$. In group 2 the tendency to the infiltrative form predominance was observed (55.5\%), but in comparison with group 1 the disseminated form predominance by 10.4 times was observed (33.3\% versus $3.2 \%$; $P<0.05)$. Other tuberculosis forms in both groups were diagnosed in a small number of patients.

In the distribution of patients by tuberculosis cases (Table 2) it was found that the incidence of tuberculosis with the MBT preserved sensitivity to AMBD and resistant tuberculosis between the study groups, both on admission and on discharge, did not differ significantly. However, the incidence 


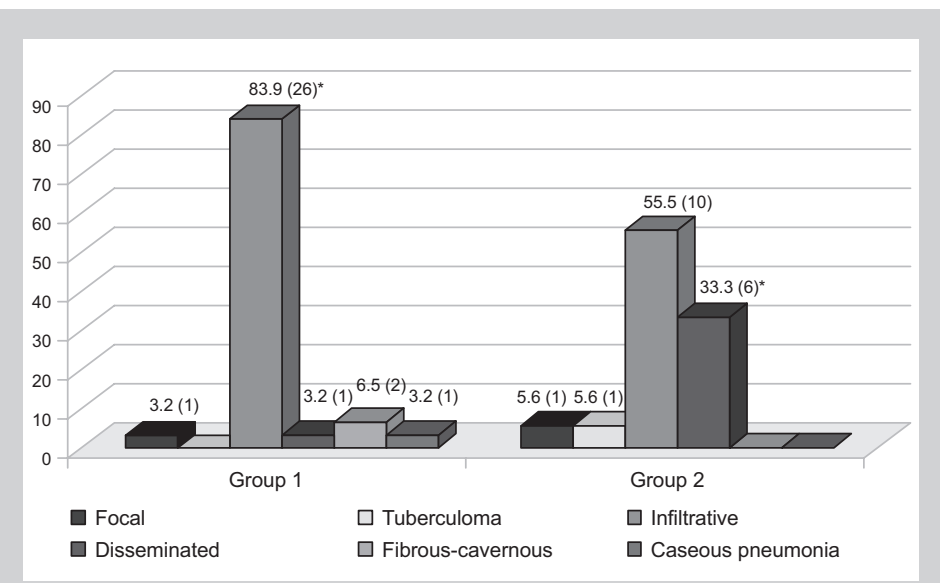

Fig. 1. Patients distribution by clinical forms, $\%$.

*: a significant difference in the indicator between the groups $(P<0.05)$;

the absolute number of patients was given in brackets.

Table 2. Distribution of patients with tuberculosis cases in the process of treatment

\begin{tabular}{|c|c|c|c|c|c|c|c|c|}
\hline \multirow[t]{3}{*}{ Cases } & \multicolumn{4}{|c|}{ Group $1(n=31)$} & \multicolumn{4}{|c|}{ Group $2(n=18)$} \\
\hline & \multicolumn{2}{|c|}{ On admission } & \multicolumn{2}{|c|}{ On discharge } & \multicolumn{2}{|c|}{ On admission } & \multicolumn{2}{|c|}{ On discharge } \\
\hline & abs. & $\%$ & abs. & $\%$ & abs. & $\%$ & abs. & $\%$ \\
\hline $\begin{array}{l}\text { Tuberculosis } \\
\text { with the MBT } \\
\text { preserved sensitivity } \\
\text { to AMBD }\end{array}$ & 18 & 58.1 & 15 & 48.4 & 11 & 61.1 & 9 & 50.0 \\
\hline $\begin{array}{l}\text { Resistant } \\
\text { tuberculosis }\end{array}$ & 13 & 41.9 & 16 & 51.6 & 7 & 38.9 & 9 & 50.0 \\
\hline
\end{tabular}

Table 3. Distribution of patients by the cavity number and size

\begin{tabular}{lllll}
\hline Cavity number and size & \multicolumn{2}{l}{ Group 1 $(\mathbf{n}=\mathbf{3 1})$} & \multicolumn{2}{l}{ Group 2 $(\mathbf{n = 1 8 )}$} \\
\cline { 2 - 5 } & abs. & $\%$ & abs. & $\%$ \\
\hline one - up to $4 \mathrm{~cm}$ & 10 & 32.3 & 6 & 33.3 \\
one - over $4 \mathrm{~cm}$ & 3 & 9.7 & 1 & 5.6 \\
2 and more - up to $4 \mathrm{~cm}$ & 9 & 29.0 & 6 & 33.3 \\
2 and more - over $4 \mathrm{~cm}$ & 3 & 9.7 & 2 & 11.1 \\
\hline
\end{tabular}

of tuberculosis with the preserved MBT sensitivity to AMBD in patients of both groups on discharge decreased due to the MBT resistant strains occurrence: in group 1 by $9.7 \%$, and in group 2 by $11.1 \%$.

FDTB, TBTF and TBR were diagnosed in the structure of TB cases (Fig. 2) with preserved MBT sensitivity to AMBD on admission to hospital in group 1, the frequency of which on discharge changed due to the fact that resistant MTB strains were found in 2 FDTB patients $(6.6 \%)$ and in 1 TBR patient (3.1\%), resulting in all 3 patients $(9.7 \%)$ transferring to category 4 with the EDRTB cases. FDTB was diagnosed in $50 \%$ in group 2 on admission to hospital, but the number of such patients on discharge decreased by 2.2 times (22.2\%). Such dynamics was due to the fact that 2 patients $(11.1 \%)$ completed the full treatment course and were transferred to category 5.1 with the RCTB diagnosis, 1 patient (5.6\%) - was transferred to category 2 with the TBTF case and - resistant MTB strains were found in 2 patients $(11.1 \%)$, resulting in the patients transferring to category 4 with the MDRTB cases. The TBR incidence in group 2 in the process remained unchanged and was $11.1 \%$.

Thus, in the structure of resistant tuberculosis cases in the process of treatment in group 1, the MDRTBR incidence remained unchanged (6.5\%), 1 patient with RifTB according to sputum culture was recorded as the MDRTB case, due to which the incidence of the MDRTB cases increased (from $25.7 \%$ to $29 \%$ ), and the incidence of the EDRTB cases increased due to the FDTB and TBR cases (from $3.2 \%$ to $12.9 \%$ ). In group 2, the incidence of the EDRTB cases remained unchanged $(11.1 \%)$, and the incidence of the MDRTB cases increased due to the FDTB and RifTB cases (from $22.2 \%$ to $38.9 \%$ ).

At the beginning of the treatment, the bacterioexcretion incidence between the groups was not significantly different: in 25 patients $(74.2 \%)$ in group 1 and in 15 patients (83.3\%) in group 2. On discharge from the hospital, the conversion incidence was not significantly different either (54.8\% and $50 \%$ respectively). However, the number of patients with bacterioexcretion in group 2 remained higher by 1.7 times (6 $(33.3 \%)$ versus $6(19.4 \%)$ in group $1, P<0.05)$. The average time of the conversion between groups did not differ significantly and was $3.4 \pm 0.5$ months in group 1 and $2.9 \pm 0.4$ months in group 2 .

The destructive process in the lungs on admission to the hospital was also diagnosed in the vast majority of patients in both groups and was not significantly different between the groups: $25(80.6 \%)$ in group 1 and $15(83.3 \%)$ in group $2(P>0.05)$. By the cavity number and size (Table 3), the significant difference between the groups was not found. As can be seen, the cavities from 1 to several sizes up to $4 \mathrm{~cm}$ in diameter: $32.3 \%$ and $29 \%$, respectively, in group 1 and $33.3 \%$ and $33.3 \%$ in group 2, were diagnosed in the vast majority of patients in both groups.

There is no significant difference in the radiological dynamics of destructive changes in the lungs in the treatment process (Fig. 3) between the groups. However, in group 2, there was a tendency to more frequent destruction healing (doubled) (33.3\% versus $16.1 \%$ ), and in group 1 - to doubled positive dynamics in the form of reduction in the number and size of destruction ( $4.2 \%$ versus $22.2 \%$ ). The average time of healing of the destructions in both groups was almost identical and amounted to $5.2 \pm 0.4$ months in group 1 and $5.3 \pm 0.4$ months in group 2 .

Following the distribution of patients by the severity of diabetes mellitus (Table 4), it was found that in group 1, the patients with almost the same frequency had a severe and moderately severe diabetes $(51.6 \%$ and $45.2 \%$ respectively), while the severe DM was diagnosed 9.2 times more frequently $(51.6 \%$ versus $5.6 \%, \mathrm{P}<0.05)$ in comparison with group 2. In group 2, almost all patients had moderately severe cases of DM $(94.4 \%)$, which is 2 times more frequent than in group $1(94.4 \%$ versus $45.2 \% ; P<0.05)$. At the same time, in group 1, the diabetes was predominantly in the subcompensation stage, which was 1.3 times more frequent than in group $1(51.6 \%$ versus $38.9 \%$; $<0.05)$. In group 2, there was a tendency to predominance of the decompensation stage 1.9 times more frequent in comparison with group 1 ( $55.5 \%$ versus $29 \%)$.

It was found that in half of patients of both groups in the setting of the tuberculosis course combined with dia- 


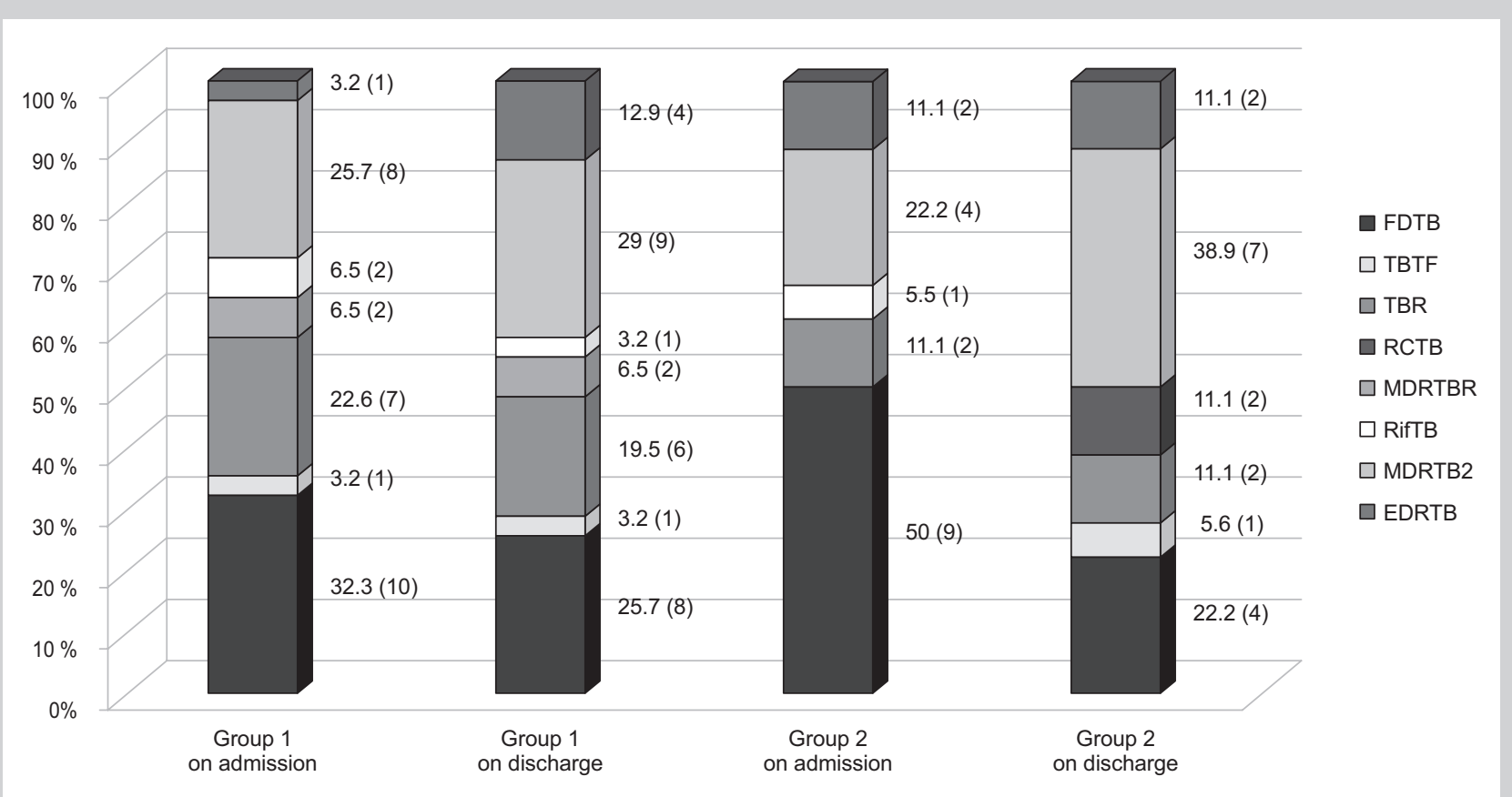

Fig. 2. Structure of the specific process cases in the study groups in the process of treatment.

The absolute number of patients is given in brackets.

betes, the concomitant conditions were also diagnosed (Fig. 4): in 17 patents (54.8\%) of group 1 and 10 patients $(55.6 \%)$ of group 2 . According to the data obtained, hypertension and pulmonary heart failure dominated in patients of group 2, both compared to group 1 (16.6\% versus $3.2 \%$ and $16.6 \%$ versus $9.7 \%$ respectively, $p<0.05$ ) and within the group. Various concomitant conditions were diagnosed in group 1, the incidence of which was neither significant nor significantly different. In this case, there was a tendency to increase the incidence of concomitant conditions such as pulmonary heart failure $(9.7 \%)$ and hepatitis (12.9\%) in patients if group 1.

There was a tendency to 1.3 times more frequent development of diabetes complications in patients of group 1 compared to group 2: 16 (51.6\%) versus 7 (38.9\%), respectively (Fig. 5), which were manifested predominantly in diabetic vascular disorders: $19.4 \%$ in retinal angiopathy and $22.6 \%$ in lower extremity angiopathy. In patients of group 2, the main manifestations of diabetes complications, registered in a small number of patients and with the same frequency, were vascular disorders $(11.1 \%$ and $11.1 \%$ respectively) and diabetic encephalopathy (11.1\%), and in 1 patient (5.6\%) diabetic foot was diagnosed. Such a small number of complications in group 2 indicates the risk of their development.

The average glucose levels in both groups were not significantly different between the two groups: $12.4 \pm 0.9$ $\mathrm{mmol} / \mathrm{L}$ in group 1 and $9.9 \pm 0.9 \mathrm{mmol} / \mathrm{L}$ in group 2 .

The incidence of adverse reactions to AMBD in group 1 was reported in 7 patients (22.6\%), among them there were cases of resistant tuberculosis in 6 patients (19.4\%), who received second line AMBD. In group 2, adverse reactions were reported in one third of patients $-6(33.3 \%), 4$ of which $(22.2 \%)$ had resistant tuberculosis cases.

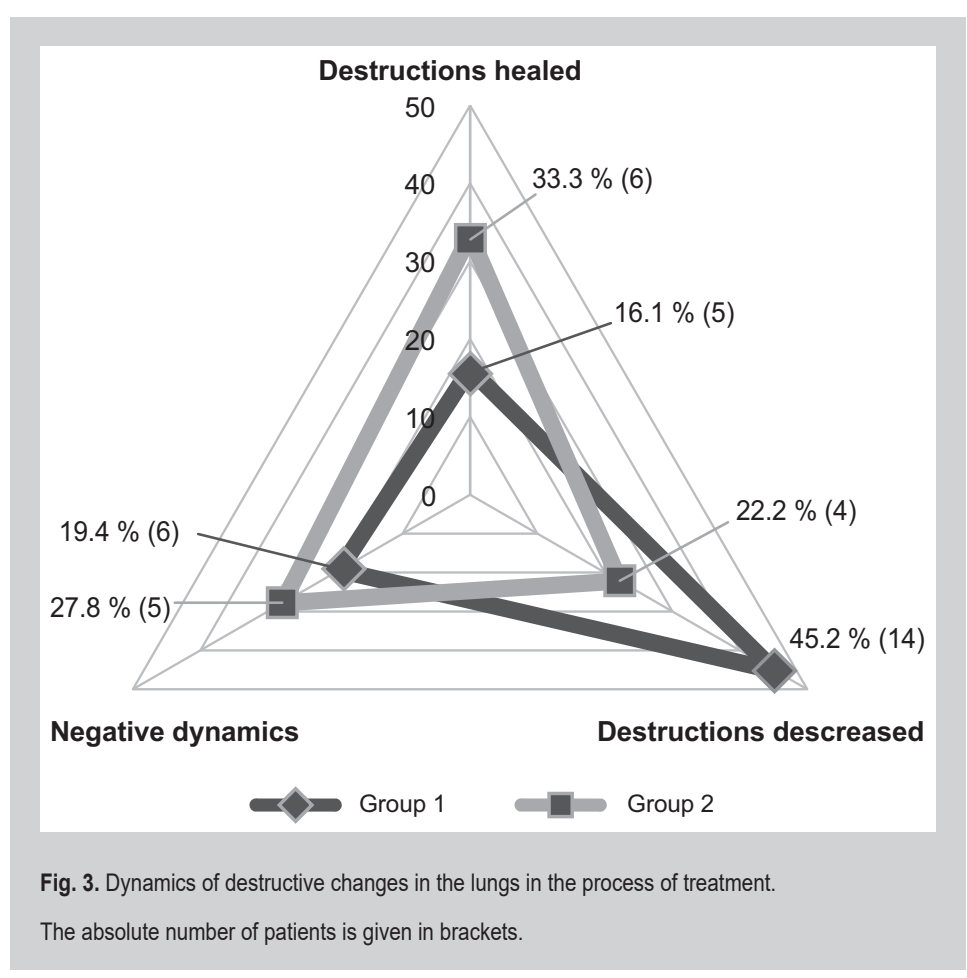

Therefore, taking into account that on discharge from the hospital, the number of resistant TB cases in group 1 was 16 , and then the incidence of adverse reactions to AMBD in this category was $37.5 \%$, and in group 2 it was $44.4 \%$ per 9 cases of resistant tuberculosis. 5 times more patients in group 2 were provided with palliative therapy on discharge from the hospital, than in group $1: 3(16.6 \%)$ versus $1(3.2 \%), P<0.05$. 
Table 4. Distribution of TB patients by the severity and DM stage

\begin{tabular}{|c|c|c|c|c|}
\hline \multirow[t]{2}{*}{ Indicator } & \multicolumn{2}{|c|}{ Group $1(n=31)$} & \multicolumn{2}{|c|}{ Group $2(n=18)$} \\
\hline & $\%$ & abs. & $\%$ & abs. \\
\hline \multicolumn{5}{|l|}{ Severity: } \\
\hline - mild & 1 & 3.2 & 0 & 0 \\
\hline - moderate & 14 & 45.2 & 17 & $94.4^{*}$ \\
\hline - severe & 16 & $51.6^{*}$ & 1 & 5.6 \\
\hline \multicolumn{5}{|l|}{ Stage: } \\
\hline - compensation & 6 & 19.4 & 1 & 5.6 \\
\hline - subcompensation & 16 & $51.6^{*}$ & 7 & 38.9 \\
\hline - decompensation & 9 & 29.0 & 10 & 55.5 \\
\hline
\end{tabular}

*: a significant difference in the indicator between the groups $(P<0.05)$.

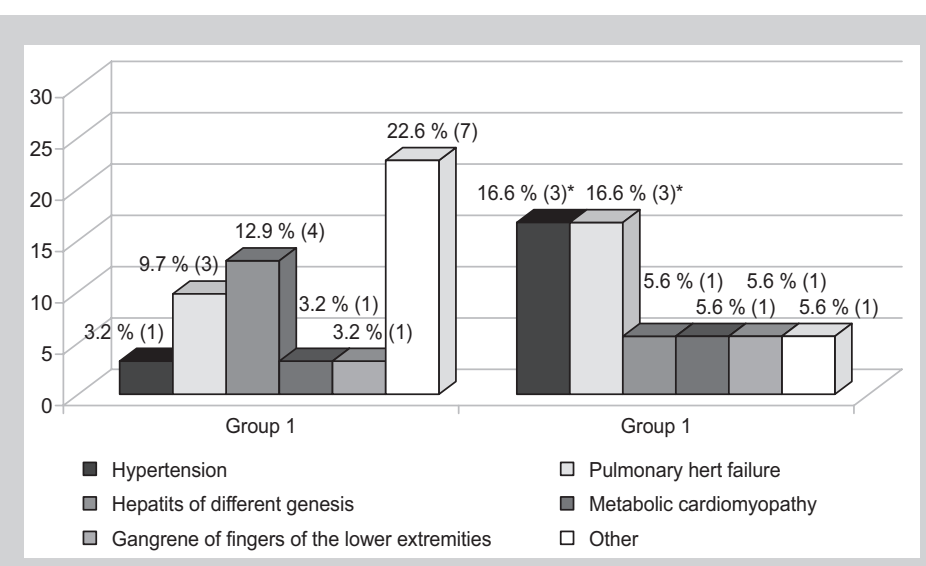

Fig. 4. Distribution of patients by concomitant conditions.

*: a significant difference in the indicator between the groups $(P<0.05)$

The absolute number of patients is given in brackets.

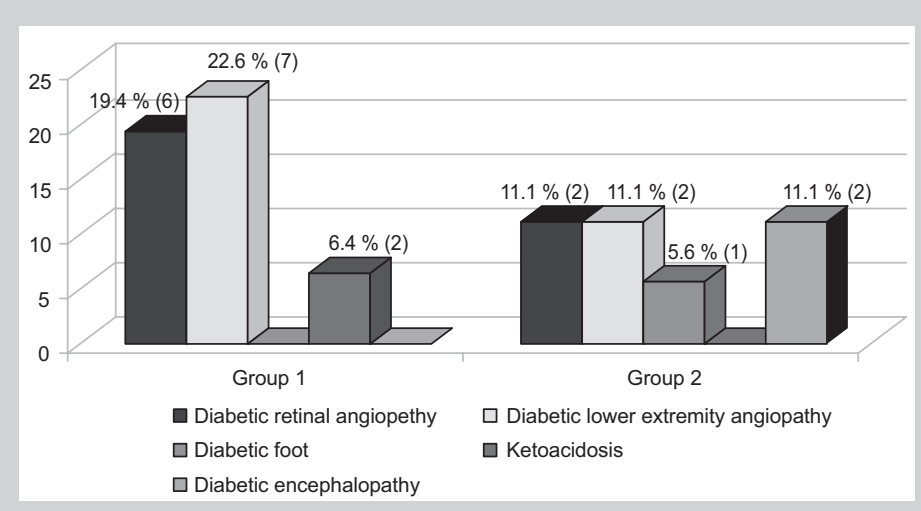

Fig. 5. Distribution of patients by diabetes complications nature.

The absolute number of patients is given in brackets.

\section{Conclusions}

On the basis of the work undertaken, the following features of the pulmonary tuberculosis course combined with different diabetes types in the Zaporizhzhia region have been determined:

1. In tuberculosis patients with the combined type 1 diabetes course, regardless of sex, young people aged 31-40 years significantly predominate, and with type $2 \mathrm{DM}-$ men over 40 years of age, which has lengthened the mean age of these patients by 12 years compared to patients with the combined type $1 \mathrm{DM}$ course.

2. In tuberculosis patients with the combined type $1 \mathrm{DM}$ course, the infiltrative form of tuberculosis is 1.5 times more frequent than that of type 2 DM $(83.9 \%$ versus $55.5 \%$; $\mathrm{P}<0.05)$. In the case of the combined type 2 DM course, the tendency towards the infiltrative form predominance ( $55.5 \%$ ) is determined, but compared to type $1 \mathrm{DM}$, the disseminated form is 10.4 times predominant (33.3\% versus $3.2 \%, \mathrm{P}<0.05)$.

3. $50 \%$ of patients with combined type $2 \mathrm{DM}$ have been admitted to hospital with the FDTB case, which is 1.5 times more frequent than with the combined type 1 DM (50\% versus $32.3 \%$ ), and with type $1 \mathrm{DM}-2$ times more frequent cases of TBR have been reported (22.6\% versus $11.1 \%$ ). On discharge from the hospital, in $11.1 \%$ of patients with the combined type $2 \mathrm{DM}$ with susceptible tuberculosis cases, MDRTB was diagnosed, and in $9.7 \%$ of patients with type 1 DM - EDRTB was diagnosed. Only patients with the combined type $2 \mathrm{DM}$ have completed a full treatment course with the RCTB diagnosis.

4. The vast number of patients in both groups are patients with bacterial excretion ( $74.2 \%$ with type $1 \mathrm{DM}$ and $83.3 \%$ with type 2 DM), and on discharge from hospital, the number of patients with bacterial excretion with the combined type 2 DM course remains 1.7 times larger (33.3\% versus $19.4 \%, P<0.05$ ).

5. Regardless of the concomitant DM type, the vast majority of patients have a destructive process in the lungs ( $80.6 \%$ of type 1 diabetes and $83.3 \%$ of type 2 DM) with a predominance of cavities up to $4 \mathrm{~cm}$ in diameter, regardless of their number.

6. Despite the fact that regardless of the concomitant DM type, the average time of the destructions healing in both groups is almost equal (5 months), in patients with type 2 DM there is a tendency to 2 times more frequent healing of destructions (33.3\% versus $16.1 \%$ ).

7. Type $1 \mathrm{DM}$ is of the predominantly severe and moderate severity ( $51.6 \%$ and $45.2 \%$ ) in the subcompensation stage $(51.6 \%)$, and type $2 \mathrm{DM}$ in almost all patients is of moderate severity $(94.4 \%$ ) with a tendency to the predominance of the decompensation stage $(55.5 \%)$.

8. Regardless of the concomitant DM type, in the half of patients in the setting of the TB course combined with $\mathrm{DM}$, the concomitant conditions are diagnosed: hypertonic disease and pulmonary heart failure in patients with the combined type $2 \mathrm{DM}$ are prevalent in comparison with the patients with type $1 \mathrm{DM}(16.6 \%$ versus $3.2 \%$ and $16.6 \%$ versus $9.7 \%, P<0.05$ ), where there is a tendency to increase in the pulmonary heart failure $(9.7 \%)$ and hepatitis (12.9\%) incidence.

9. In TB patients, the complications of DM develop 1.3 times more frequent with type 1 than with type 2 (51.6\% versus $38.9 \%$ ), which are manifested predominantly by diabetic vascular disorders, namely, retinal angiopathy and lower extremity angiopathy and ketoacidosis. And complications of type 2 DM are diabetic: vascular disorders, encephalopathy and diabetic foot.

10. Regardless of the concomitant diabetes type, the incidence of adverse reactions to AMBD in cases of resistant tuberculosis is $37.5 \%$ in patients with the combined type 1 DM and $44.4 \%$ with the combined type 2 DM. 
11. In cases of tuberculosis with the combined type $2 \mathrm{DM}$, 5 times more patients have been provided with the palliative therapy $(16.6 \%$ versus $3.2 \%)$.

\section{References}

[1] Shalmin, A. S., Raznatovskaya, E. N., Bobrovnichaya-Dvizova, Yu. M., Dvizov, A. V., Malyar, N. V., \& Fedchenko, T. S. (2012). Osobennosti sochetannogo techeniya tuberkuleza legkikh i sakharnogo diabeta [Features of the combined flow of pulmonary tuberculosis and diabetes mellitus]. Pathologia, 1(24). 92-94. [in Ukrainian].

[2] Komissarova, O. G., Kossij, Yu. E., Abdullaev, R. Yu., Moiseeva, S. V., \& Vasil'eva, I. A. (2013). Osobennosti techeniya i e'ffektivnost' lecheniya tuberkuleza legkikh s mnozhestvennoj lekarstvennoj ustojchivost'yu vozbuditelya u bol'nykh s raznymi tipami sakharnogo diabeta [Features of the course and efficacy of treatment of pulmonary tuberculosis with multiple drug-resistant pathogens in patients with different types of diabetes mellitus]. Tuberkulez i bolezni legkikh, 90(3), 010-014. [in Russian].

[3] Dedov, I. I. (2012) Sakharnyj diabet - opasnejshij vyzov mirovomu soobschestvu [Diabetes mellitus - a dangerous treat to the mankind]. Vestnik Rossijskoj akademii medicinskikh nauk, 67(1), 7-13. doi: 10.15690/ vramn.v67i1.103. [in Russian].

[4] (2012). Nakaz Ministerstva okhorony zdorovia Ukrainy «Ukraina MOZ Unifikovanyi klinichnyi protokol pervynnoi ta vtorynnoi (spetsializovanoi) medychnoi dopomohy. Tsukrovyi diabet 2 typu» vid 21 hrudnia 2012 roku №1118 [Order of the Ministry of Health of Ukraine Unified clinical protocol of primary and secondary (specialized) medical care. Type 2 diabetes mellitus from December 21, 2012 №1118]. Kyiv [in Ukrainian].

[5] Komissarova, O. G., Konyayeva, O. O., Berezhnaya, O. O., Abdullayev, R. Yu., \& Vasilyeva I. A. (2015). E'ffektivnost' lecheniya bol'nykh tuberkulezom legkikh s mnozhestvennoj i shirokoj lekarstvennoj ustojchivost'yu vozbuditelya v sochetanii s raznymi tipami saharnogo diabeta [Efficacy of Treatment of Patients with Multiple and Extensively Drug-Resistant Pulmonary Tuberculosis Combined with Different Types of Diabetes Mellitus]. Vestnik Rossijskogo gosudarstvennogo medicinskogo universiteta, 3, 33-37. [in Russian].

[6] (2014). Nakaz Ministerstva okhorony zdorovia Ukrainy «Ukraina. MOZ. Unifikovanyi klinichnyi protokol pervynnoi, vtorynnoi (spetsializovanoi) ta tretynnoi (vysokospetsializovanoi) medychnoi dopomohy doroslym. Tuberkuloz» vid 31 hrudnia 2014 roku №620 [Unified clinical protocols of primary, secondary (specialized) and tertiary (highly specialized) medical care for adults "Tuberculosis" from December, 31, 2014 №620] [in Ukrainian].

\section{Information about authors:}

Raznatovska 0. M., MD, PhD, DSc, Associate Professor, Professor of the Department of Phthisiology and Pulmonology Zaporizhzhia State Medical University, Ukraine.

Bobrovnycha-Dvizova Yu. M., MD, Post-graduate student of the Department of Phthisiology and Pulmonology Zaporizhzhia State Medical University, Ukraine.

\section{Відомості про авторів:}

Разнатовська О. М., А-р меА. наук, Аоцент, професор каф. фтизіатрії і пульмонології, Запорізький Аержавний медичний університет, Україна.

Бобровнича-Авізова Ю. М., аспірант каф. фтизіатрії і пульмонології, Запорізький державний медичний університет, Україна.

\section{Сведения об авторах:}

Разнатовская Е. Н., А-р меА. наук, Аоцент, профессор каф. фтизиатрии и пульмонологии, Запорожский государственный медицинский университет, Украина. Бобровничая-Авизова Ю. М., аспирант каф. фтизиатрии и пульмонологии, Запорожский государственный меАицинский университет, Украина.

Конфлікт інтересів: віАсутній.

Conflicts of Interest: authors have no conflict of interest to declare. 